\title{
Complete Genome Sequence of the Fire Blight Pathogen Erwinia amylovora CFBP 1430 and Comparison to Other Erwinia spp.
}

\author{
Theo H. M. Smits, ${ }^{1}$ Fabio Rezzonico, ${ }^{1}$ Tim Kamber, ${ }^{1}$ Jochen Blom, ${ }^{2}$ Alexander Goesmann, ${ }^{2}$ \\ Jürg E. Frey, ${ }^{1}$ and Brion Duffy ${ }^{1}$ \\ ${ }^{1}$ Agroscope Changins-Wädenswil ACW, Division of Plant Protection, Swiss National Competence Center for Fire Blight, $\mathrm{CH}-$ \\ 8820 Wädenswil, Switzerland; ${ }^{2} \mathrm{CeBiTec}$, University of Bielefeld, Bielefeld, Germany
}

Submitted 10 October 2009. Accepted 25 November 2009.

\begin{abstract}
Fire blight, caused by the enterobacterium Erwinia amylovora, is a devastating disease of rosaceous plants that has global economic importance for apple and pear production and trade. The complete genome of $E$. amylovora CFBP 1430 was sequenced, annotated, and compared with the genomes of other Erwinia spp. Several singleton and shared features of the $E$. amylovora CFBP 1430 genome were identified that offer a first view into evolutionary aspects within the genus Erwinia. Comparative genomics identified or clarified virulence and fitness determinants and secretion systems. Novel insights revealed in the genome of $E$. amylovora CFBP 1430 hold potential for exploitation to improve the design of more effective fire blight control strategies.
\end{abstract}

Erwinia amylovora (Enterobacteriaceae) causes fire blight, the most important threat to pome fruit production (i.e., apple, pear, and quince) globally, and it affects a wide variety of Rosaceae (primarily Maloideae), including ornamental and native forest species important in rural economies, cultural heritage, and landscape ecosystems (Duffy et al. 2005). E. amylovora was the first bacterial plant pathogen described (in the late 1790s) and originated in North America, from where it has relatively recently spread first to New Zealand in the 1910s, to the United Kingdom and Northern Europe in the late 1950s, and more widely in Europe and the Middle East in the 1960s (Bonn and van der Zwet 2000). E. amylovora has quarantine status outside North America, and it is a contentious trade issue in fruit with fire-blight-free countries such as Australia, Japan, and all areas of the Southern Hemisphere aside from New Zealand (Calvin and Krissoff 1998; Roberts et al. 1998). This invasive pathogen continues to spread across Europe and the Middle East, with advance eastward threatening the native origin of apple germplasm resources in Central Asia (Jock et al. 2002), adding to the urgency for better understanding the disease and pathogen in order to develop more effective control and containment strategies.

T. H. M. Smits and F. Rezzonico contributed equally to this article, and should both be regarded as first authors.

Corresponding author: B. Duffy; Telephone: +41.44.783.6416; Fax: +41.44.783.6305; E-mail: duffy@acw.admin.ch

* The $\boldsymbol{e}$-Xtra logo stands for "electronic extra" and indicates that three supplementary figures, three supplementary tables, and supplementary results information are available online.
Fire blight is so named because epidemics can rapidly develop, resulting in scorched symptoms, with kill of trees or entire orchards within a single growing season leading to devastating economic losses (Bonn and van der Zwet 2000). Typical symptoms include flower necrosis, immature fruit rot, shoot recurvature (syn. shepherd's crook), profuse bacterial ooze, and cankers on woody tissues. E. amylovora enters hosts through natural openings (e.g., flower nectaries and leaf hydathodes) and wounds (e.g., mechanical injury and insect or hail damage). The disease develops as blossom, shoot, or rootstock blight depending on the plant tissues infected and affected, and each syndrome requires specific control strategies (Thomson 2000). E. amylovora population growth is highly dependent on weather conditions, which has been used to develop disease forecasting models for blossom blight, and it is efficiently vectored by flower-foraging insects, especially honeybees, in a presumably passive association (Johnson and Stockwell 1998). E. amylovora is considered to have poor ecological fitness outside host or surrogate plants (Thomson 2000).

Current control efforts rely primarily on antibiotic applications (e.g., streptomycin and oxytetracycline) to protect flowers (with major controversy and outright bans in many countries due to concerns about possible antibiotic resistance development) (McManus et al. 2002), moderately effective biocontrol applications (Johnson and Stockwell 1998), or plant growth regulators (i.e., prohexadione-Ca) (Halbwirth et al. 2003). Commercial cultivars of apple and pear are, for the most part, highly susceptible, and continued efforts to breed high-level resistance have been inadequate thus far (Norelli et al. 2003). Understanding the genetic mechanisms for virulence may lead to the design of improved disease control strategies. Although important insights have been garnered regarding this cardinal phytopathogenic bacterium relative to other pathogens, much remains uncertain about the genetics of E. amylovora (Oh and Beer 2005). Recently, complete genome sequencing of a key species representing the related pectolytic-group of ex. Erwinia (Pectobacterium atrosepticum SCRI 1043) has enhanced design of novel control strategies (Toth et al. 2006). Availability of a published complete genome for the preeminent species of necrotrophic true Erwinia is anticipated to have a similar practical impact, as well as provide basic scientific information on evolution and relatedness of the species within the Erwinia genus. Here, we present the complete genome sequence of E. amylovora and provide comparison with related phytopathogenic and nonpathogenic species. 


\section{RESULTS AND DISCUSSION}

\section{Complete genome of E. amylovora CFBP 1430.}

E. amylovora CFBP 1430 was isolated in 1972 from a Crataegus sp. (Paulin and Samson 1973) and later used as a standard strain in many genetic and biochemical studies (Gaudriault et al. 1997; Dellagi et al. 1998). The complete genome sequence of E. amylovora CFBP 1430 (Fig. 1) was obtained using Illumina sequencing technology and assembled against the unpublished sequence of E. amylovora Ea273
(Bocsanczy et al. 2008). EMBL accession numbers for the genome sequence of E. amylovora CFBP 1430 are FN434113 (chromosome) and FN434114 (pEa29).

Overall, the genome sequences of the European (CFBP 1430) and U.S. (Ea273) strains were found to be nearly identical (>99.99\%), with only a low number of nucleotide differences. This low number of nucleotide changes reinforces prior indications of low diversity within this pathogen and suggests that minimal evolution has occurred since E. amylovora global dispersal. The E. amylovora CFBP 1430 chromosome is $301 \mathrm{bp}$

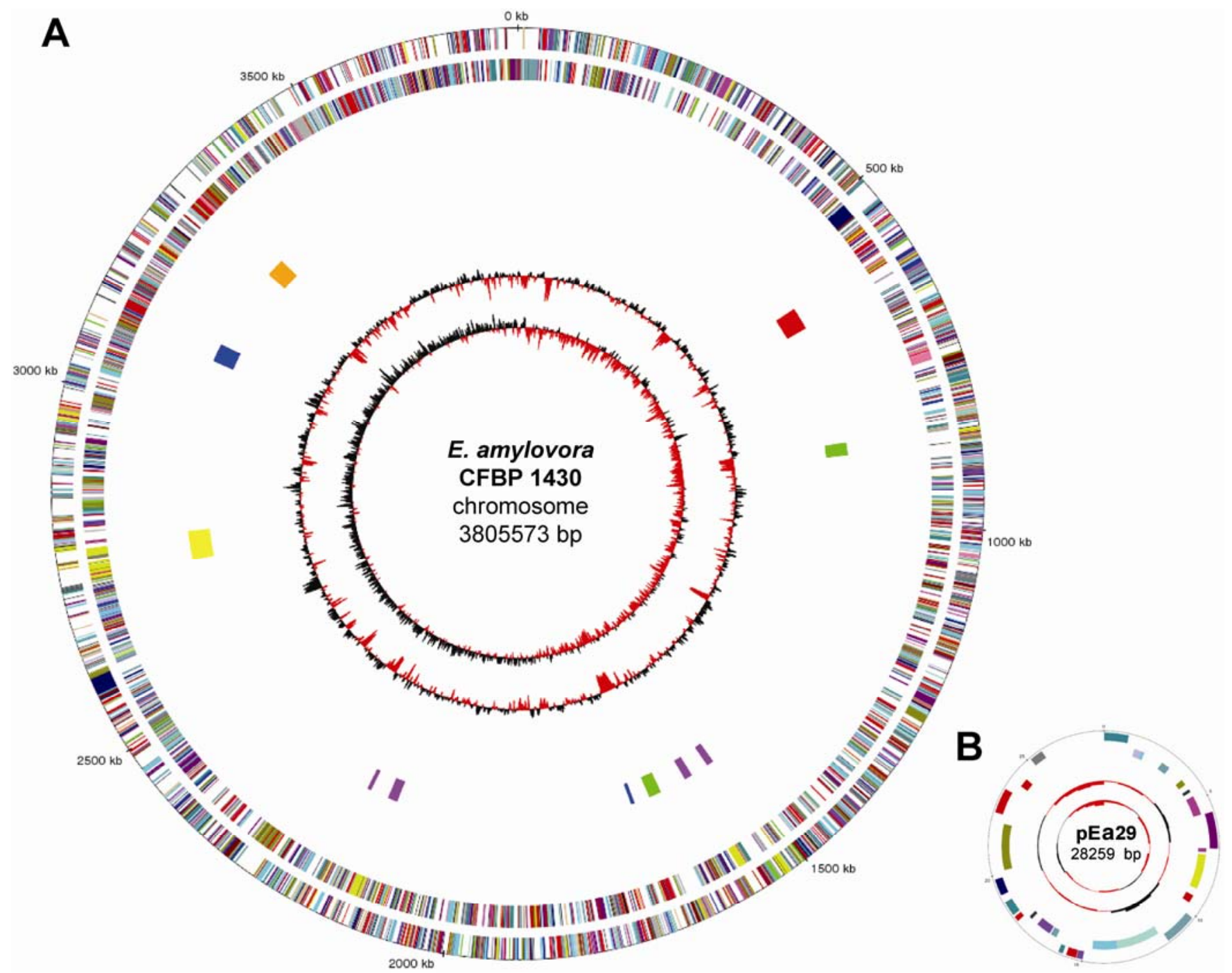

Fig. 1. Circular representation of the A, chromosome and B, plasmid pEa29 (not to same scale) of Erwinia amylovora CFBP 1430. Circles (from outside to inside): first, scale bar in kilobases; second and third, predicted coding sequences of E. amylovora CFBP 1430 chromosome on the leading and lagging strand, respectively (colors according to COGs); fourth (A only), coding sequences of the hrp/hrc type III secretion system(T3SS) (red), the inv/spa T3SS (green), the type VI secretion system clusters 1, 2 (blue), and 3 (orange), the flagellar genomic island (yellow), and dispersed flagellar gene clusters (purple); fifth, G+C content; sixth, G+C skew.

Table 1. General characteristics of the genome of Erwinia amylovora CFBP 1430 compared with E. amylovora Ea273

\begin{tabular}{|c|c|c|c|c|c|}
\hline \multirow[b]{2}{*}{ Strain } & \multicolumn{2}{|c|}{ E. amylovora CFBP 1430} & \multicolumn{3}{|c|}{ E. amylovora Ea273 } \\
\hline & Chromosome & pEa29 & Chromosome & pEa72 & pEa29 \\
\hline Size (bp) & $3,805,573$ & 28,259 & $3,805,874$ & 71,487 & 28,243 \\
\hline Average coverage & 39.28 & 77.04 & $\ldots$ & $\ldots$ & $\ldots$ \\
\hline Calculated copy number & 1 & 1.96 & $\ldots$ & $\ldots$ & $\ldots$ \\
\hline $\mathrm{G}+\mathrm{C}$ content $(\%)$ & 53.60 & 50.24 & 53.60 & 55.70 & 50.24 \\
\hline Predicted no. of CDS & 3,706 & 28 & $\ldots$ & $\ldots$ & $\ldots$ \\
\hline No. of rRNA operons & 7 & 0 & $\ldots$ & $\ldots$ & $\ldots$ \\
\hline No. of tRNAs & 78 & 0 & $\ldots$ & $\ldots$ & $\ldots$ \\
\hline
\end{tabular}


smaller than that of E. amylovora Ea273 (Table 1), and this is largely due to intergenomic intergenic transcribed spacer (ITS) variation (discussed below).

\section{Comparative genomic analysis}

of E. amylovora strains CFBP 1430 and Ea273.

MAUVE alignment of both E. amylovora strains CFBP 1430 and Ea273 (Fig. 2) revealed a large-scale rearrangement of the genome. Two independent recombination events appear to have occurred within copies of the ribosomal (r)RNA operon. The recombination events resulted in a position exchange of two sizable regions of the chromosome (Fig. 2). This rearranged chromosomal organization would explain differences observed in the pulsed-field gel electrophoresis (PFGE) patterns when the genomic DNA of these strains is digested using the restriction enzyme XbaI (Zhang and Geider 1997). In silico analyses predicted the presence of the exact fragment sizes used to classify E. amylovora CFBP 1430 as a Pt-3 genotype pattern and the band profile of E. amylovora Ea273 as a Pt-X or Pt-4 genotype (Zhang and Geider 1997). Thus, other described PFGE Pt genotypes will probably be similarly clarified after genome sequencing of their representative strains.

\section{Plasmids.}

The E. amylovora CFBP 1430 genome lacks plasmid $\mathrm{pEa} 72$, in contrast to the genome of E. amylovora Ea273 (Fig. 2; Table 1 ). It is described that E. amylovora CFBP 1430 carries only a single plasmid (Llop et al. 2006), and this has been confirmed with our complete genome sequencing. Plasmid pEa29 is found in all but a few anomalous strains of E. amylovora (Llop et al. 2006) and primers targeting pEa29 sequences are routinely used for specific pathogen detection and diagnosis of fire blight (Llop et al. 2000; Salm and Geider 2004).

In E. amylovora CFBP 1430, the known 8-bp repeat region of $\mathrm{pEa} 29$ contained five repeats, unlike the four repeats identified in Ea273 (Schnabel and Jones 1998; Kim and Geider 1999). At a different location on $\mathrm{pEa} 29$ in E. amylovora CFBP1430, another 8-bp insertion was identified in a designated repeat region (McGhee and Jones 2000), rendering the sequence of pEa29 in this strain a total of 16 bp longer than in E. amylovora Ea273. The $\mathrm{pEa} 29$ variant in $E$. amylovora CFPB 1430 is considerably more divergent from the variant in E. amylovora Ea88 (McGhee and Jones 2000).

Inter- and intragenomic variation within rRNA operons.

Seven rRNA operons were amplified from the genome of $E$. amylovora CFBP 1430 and completely sequenced using the Sanger method to preclude biases that may occur within these regions (McGhee et al. 2002). Several obvious differences between the seven individual rRNA operons were detected. Based on a sequence alignment, it was observed that the ITS regions between the $16 \mathrm{~S}$ and $23 \mathrm{~S}$ rRNA genes of three operons of $E$. amylovora CFBP 1430 were composed of ITS regions having the transfer $(\mathrm{t}) \mathrm{RNA}-\mathrm{Ala}$ and tRNA-Ile genes, and of four operons containing the tRNA-Glu. This is different from the E. amylovora Ea273 genome, where four tRNA-Ala/tRNA-Ile-operons and three tRNA-Glu-operons were found, a situation that deviates from the described variation in ITS regions for other $E$. amylovora strains (McGhee et al. 2002). When using the ITS allele designations of McGhee and associates (2002), E. amylovora $\mathrm{CFBP} 1430$ has the ITS type $\mathrm{X}^{+} ; \mathrm{X}^{-} ; \mathrm{X}^{+} 139 ; \mathrm{X}^{-} 139 ; \mathrm{Y}^{+}$ 139 , $\left(\mathrm{Y}^{-} 139\right)_{2}$, that is comparable to strain Ea110 although, in that strain, the seventh copy was not determined.

Five of seven copies of the rRNA operon have a 99-bp insertion within the $23 \mathrm{~S}$ rRNA gene, mapped within helix 45 and probably representing an intervening sequence (IVS), as already described within many species within the Enterobacteriaceae family and other bacteria (Pronk and Sanderson 2001). We confirmed with polymerase chain reaction (PCR) that this corresponds to a 5:2 ratio between 23S rRNA gene copies with and without this IVS. BlastN analysis showed that the IVS sequences are present in all seven copies of the 23S rRNA gene of E. pyrifoliae DSM $12163^{\mathrm{T}}$ but are absent in the E. tasmaniensis Et1/99 (Kube et al. 2008) and P. atrosepticum SCRI 1043 (Bell et al. 2004) genomes. The ITS2 region between the $23 \mathrm{~S}$ and the 5S rRNA genes varies also in sequence and length between individual copies of the rRNA operons within the E. amylovora CFBP 1430 genome. Two different versions of 213 and $219 \mathrm{bp}$ were found with a 4:3 ratio in E. amylovora CFBP 1430 whereas, in E. amylovora Ea273 genome, this ratio is 5:2.

Clustered regularly interspaced short palindromic repeats.

Clustered regularly interspaced short palindromic repeats (CRISPR) and CRISPR-associated sequence (CAS) proteins constitute a putative prokaryotic RNA-interference-based immune system (Makarova et al. 2006; Sorek et al. 2008) protecting against bacteriophages or plasmids (Mojica et al. 2005). The annotation of the genome of E. amylovora CFBP 1430 revealed eight genes with homology to so-called cas-genes (EAMY 2813 to EAMY_2820) (Haft et al. 2005). Using the CRISPRFinder (Grissa et al. 2007), three regions were identified containing the CRISPR with 36, 34, and 5 CRISPR units (consisting of repeat and spacer). Some of the spacers have homology to known sequences. Three of the spacers have high sequence identity to regions in plasmid pEt35 of E. tasmaniensis Et1/99, while one matches the ColE1-type replication region of many plasmids, including pSW100 of Pantoea stewartii subsp. stewartii SW2. A few others have homology to regions in genomes of Salmonella spp. that encode phage-derived genes. The total number of identified spacers ( 9 of 75) is in the range of currently described CRISPR systems in other bacteria (Mojica et al. 2005; Makarova et al. 2006) but higher than the average.

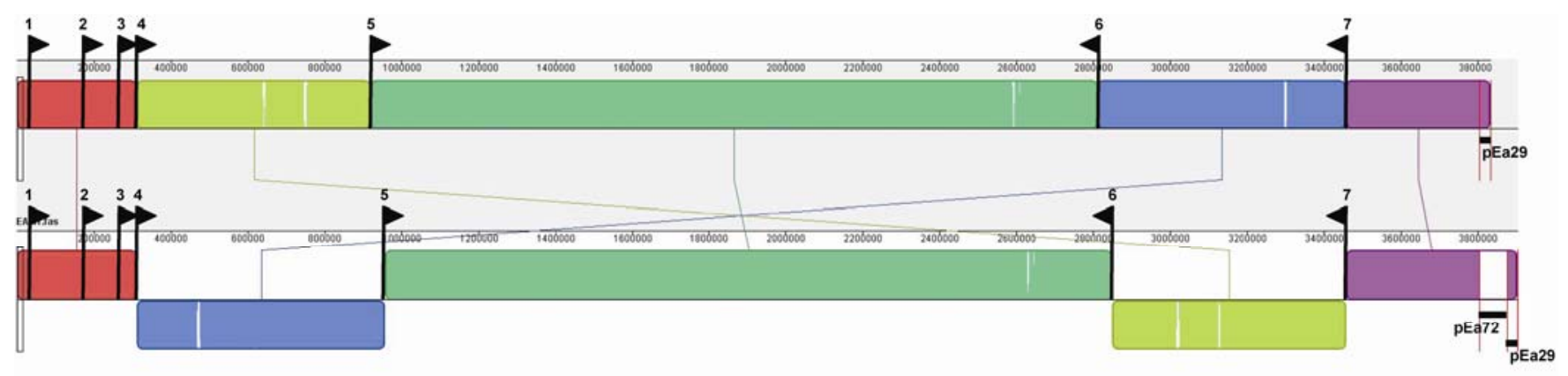

Eazratean

Fig. 2. MAUVE alignment of the genome sequences of Erwinia amylovora CFBP 1430 and E. amylovora Ea273. Vertical lines indicate ribosomal (r)RNA operons. Numbers indicate the rRNA operon numerator, as used in the alignments. Arrows indicate the transcriptional direction of the rRNA operons. 
The repeats of CRISPR regions 1 and 2 are 29 bp in length with spacers of 32 to $33 \mathrm{bp}$ while CRISPR region 3 has repeats of 26 and 34 to $35 \mathrm{bp}$ spacers. The repeats from CRISPR region 1 are only slightly different from the repeats in CRISPR region 2 but differ significantly from those of CRISPR region 3 . The number of repeats in E. amylovora CFBP 1430 deviates from the number of repeats found in the genome sequence of E. amylovora Ea273. Here, CRISPR region 1 contains one more CRISPR unit. From BLASTN searches, the additional spacer region is $100 \%$ identical to bases 19506 to 19475 in plasmid pEU30 of E. amylovora UTRJ2 (Foster et al. 2004) complementary to the virB4 gene. Within CRISPR region 2, two additional CRISPR units were found. One CRISPR unit (spacer 14) has no homology to database sequences, while spacer 31 is $100 \%$ identical to the complement of bases 13305 to 13336 in plasmid pEa72 of E. amylovora Ea273.

\section{Whole-genome structure comparison of the genomes of E. amylovora CFBP 1430, E. pyrifoliae DSM 12163' ${ }^{\mathrm{T}}$, and $E$. tasmaniensis Et1/99.}

Currently, complete genome sequences are available for three true Erwinia spp.: E. amylovora CFBP 1430, E. pyrifoliae DSM 12163 ${ }^{\mathrm{T}}$ (Smits et al. 2010), and E. tasmaniensis Et1/99 (Kube et al. 2008). We compared these using MAUVE in the progressive mode. A comprehensive analysis of this comparison indicating significant and relevant dissimilarities in gene content is provided in Figure 3.

Overall, colinearity was observed for the chromosomes of all three species (Supplementary Fig. 1), despite notable largescale chromosomal reorganizations (Fig. 3). This is consistent with our results from the manual annotation process (i.e., orthologous coding sequences [CDS] in E. amylovora CFBP 1430 have approximately $95 \%$ sequence identity to $E$. pyrifoliae DSM $12163^{\mathrm{T}}$ and approximately $90 \%$ sequence identity to E. tasmaniensis Et1/99). In contrast to these other two species, sizable phage-gene-containing regions were not detected in the E. amylovora CFBP 1430 genome, although remnants of such were identified. Only a few large-scale chromosomal reorganizations appear to have occurred since the divergence of these three species.

Plasmids in these ecologically distinct Erwinia spp. have low sequence similarity. The only two plasmids where, to a cer- tain degree, colinearity was observed are the E. amylovora CFBP 1430 plasmid pEa29 and E. pyrifoliae DSM $12163^{\mathrm{T}}$ plasmid pEa36, as previously reported (McGhee et al. 2002). The five plasmids of E. tasmaniensis Et1/99 (Kube et al. 2008) and the three small plasmids of E. pyrifoliae DSM12163 (Smits et al. 2010) are not related to these plasmids or to each other. However, large segments of pEa29 were found in the chromosome of E. tasmaniensis Et1/99 (Fig. 3), with genes that encode the thiamine biosynthesis proteins ThiOSGF, the high-affinity choline transporter BetT, the peptide methionine sulfoxide reductase MsrA, the histone-like nucleotide structuring protein $\mathrm{H}-\mathrm{NS}$, the putative aldehyde dehydrogenase AldD, and a LysR-family transcriptional regulator. Using plasmidcured strains (Llop et al. 2008) and deletion mutants (McGhee and Sundin 2008), these genes have been shown to play a minor role in the virulence of E. amylovora.

\section{Gene content comparison among $E$. amylovora, $E$. pyrifoliae, and $E$. tasmaniensis genomes.}

We compared complete genomes of three Erwinia spp. in order to i) resolve the Erwinia core genome and ii) identify differences that clarify the basis of E. amylovora pathogen success in contrast to E. pyrifoliae, which has a considerably limited host range on pome fruit, and E. tasmaniensis Et1/99, which is a pome fruit epiphyte and not reported to be a phytopathogen of other species.

A Venn diagram (Fig. 4) was calculated using the program EDGAR, which employed a reciprocal BLAST on all CDS of the three species with a cut-off of $70 \%$ of protein sequence identity over at least $70 \%$ of the protein. This Venn diagram revealed 2,474 core CDS, corresponding to approximately two-thirds of all CDS in these genomes. Analysis of the singletons in each genome revealed a large majority that could only be annotated as hypothetical proteins. Just a fraction of predicted proteins were shared between any two of the three species. E. amylovora CFBP 1430 and E. pyrifoliae DSM $12163^{\mathrm{T}}$ had many more shared genes in comparison with the putative nonpathogen E. tasmaniensis Et1/99 and the other two Erwinia spp. Shared genes between the two phytopathogens had a higher sequence identity (approximately $95 \%$ for core genes) compared with E. tasmaniensis Et1/99 (approximately 90\%). Relevant singletons of E. amylovora CFBP 1430

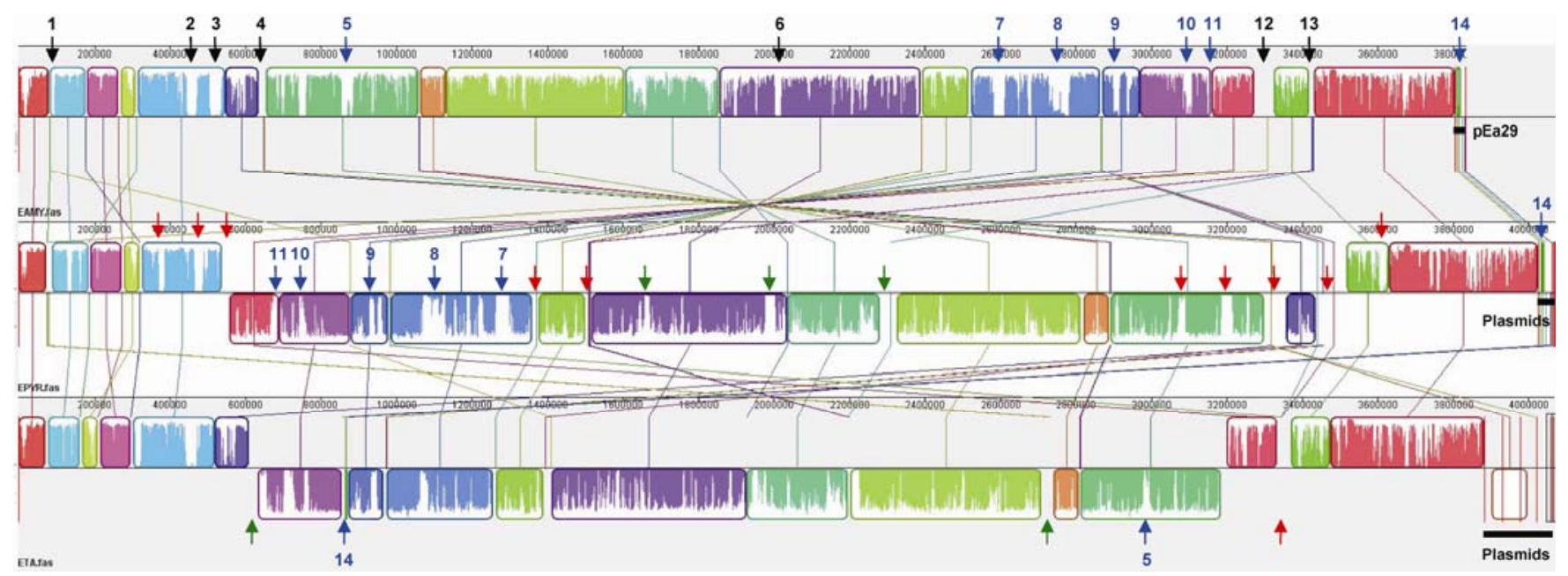

Fig. 3. MAUVE alignment of the genomes of Erwinia amylovora CFBP 1430, E. pyrifoliae DSM 12163 ${ }^{\mathrm{T}}$, and E. tasmaniensis Et1/99. Selected features have been indicated with arrows and important features in E. amylovora CFBP 1430 are indicated with numbers. Colors represent different types of features: black, singleton features in E. amylovora CFBP 1430 (Supplementary Table 1); blue, selected features shared between E. amylovora CFBP and either E. pyrifoliae DSM $12163^{\mathrm{T}}$ or E. tasmaniensis Et1/99 (Supplementary Table 2); red, genomic islands; and green, phage-gene-containing regions. Number 14 represents the shared regions between E. amylovora CFBP 1430 plasmid pEa29, E. pyrifoliae DSM $12163^{\mathrm{T}}$ plasmid pEP36, and the chromosome of E. tasmaniensis Et1/99. 
and relevant features shared between $E$. amylovora CFBP 1430 and E. pyrifoliae DSM $12163^{\mathrm{T}}$ or E. tasmaniensis Et1/99 are discussed in detail below.

\section{Multiple type III secretion systems.}

The genome of E. amylovora CFBP 1430 encodes three type III secretion systems (T3SS). The hypersensitive response and pathogenicity (Hrp) T3SS, encoded by the so-called pathogenicity island 1 (PAI-1), is an established pathogenicity factor in E. amylovora that functions in delivery of effector proteins into the eukaryotic host (He et al. 2004; Oh et al. 2005). Two inv/spa-type T3SS islands (PAI-2 and PAI-3), more similar to the SPI1 T3SS of Salmonella typhimurium LT-2 (McClelland et al. 2001) and the inv/spa T3SS of the insect endosymbiont Sodalis glossidinius str. morsitans (Dale et al. 2001), respectively, were identified in the genomes of both E. amylovora strains CFBP 1430 and Ea273 (Bocsanczy et al. 2008).

The Hrp T3SS of E. amylovora CFBP 1430 is composed of 27 genes (EAMY_0525-EAMY_0551), arranged in three transcriptional units plus regulatory genes (Oh et al. 2005). E. amylovora CFBP 1430 carries two notable singletons (ORFU1 and ORFU2, EAMY_0540-EAMY_0541) located between the $h r p A$ and $h r p S$ genes (Kube et al. 2008; Smits et al. 2010). The hrp region in E. amylovora CFBP 1430 is located between the hrp effector and elicitors regions (HEE) (EAMY_0552EAMY_0558) and the Hrp-associated enzymes (HAE) (EAMY_0519-EAMY_0524) region (Oh et al. 2005). The HEE region includes the two harpin genes ( $h r p N$ and $h r p W$ ), a gene $(d s p A / E)$ coding for a secreted effector essential for $E$. amylovora pathogenicity (Boureau et al. 2006), and a set of chaperone genes (ORFA, ORFB, ORFC, and $d s p B / F$ ). The HAE region of E. amylovora CFBP 1430 (and of Ea273) comprises the $h r p$-associated systemic virulence genes $(h s v A B C)$, the $h r p K$ gene encoding for a putative T3SS translocator (PetnickiOcwieja et al. 2005), and two genes encoding proteins of unknown function. A large segment of the HAE region is absent in E. tasmaniensis Et1/99 (Fig. 3).

Two inv/spa-type T3SSs, PAI-2 (EAMY_0771-EAMY_0792) and PAI-3 (EAMY_1573-EAMY_1593), both located on low $\mathrm{G}+\mathrm{C}$ regions of the genome and consisting of 22 and 21 genes, respectively, were identified in the genome of $E$. amylovora CFBP 1430. PAI-3 is closely related to the complete inv/spa systems recently found in both E. tasmaniensis Et1/99 and E. pyrifoliae DSM $12163^{\mathrm{T}}$ (Kube et al. 2008; Smits et al. 2010), whereas PAI-2 shows higher homology to the second, incomplete inv/spa-cluster of E. tasmaniensis Et1/99 (Kube et al. 2008) and is absent in E. pyrifoliae DSM $12163^{\mathrm{T}}$. This suggests that both PAI-2 and PAI-3 were acquired prior to the divergence of these three species within the Erwinia genus (both are absent in pectolytic Pectobacterium carotovorum), whereas PAI-2 was lost entirely in E. pyrifoliae DSM $12163^{\mathrm{T}}$ and partially in the putatively nonpathogenic species E. tasmaniensis Et1/99.

The function of these two inv/spa-type T3SSs is still unknown, although it was demonstrated that they may not directly be involved in virulence in plants (Zhao et al. 2009). Considering the resemblance of PAI-2 and especially PAI-3 to the T3SS of the insect endosymbiont $S$. glossidinius str. morsitans (Dale et al. 2001), these inv/spa-type T3SSs may contribute to as-yet-unknown associations between $E$. amylovora and insect vectors.

\section{Additional T3SS effectors.}

Genome-wide comparison of E. amylovora CFBP 1430 with E. pyrifoliae DSM $12163^{\mathrm{T}}$ (Smits et al. 2010) and E. tasmaniensis Et1/99 (Kube et al. 2008) revealed three singleton genes identified as putative T3SS effectors that may contribute to the broader host range of E. amylovora. The eop2 gene (EAMY 0653) encodes the T3SS helper protein Eop2, which has a Cterminal pectate lyase domain (Grant et al. 2006; Nissinen et al. 2007) and is secreted but apparently not translocated in Pseudomonas syringae (Chang et al. 2005), where it elicits a hypersensitive response in tobacco apoplasts (Alfano and Collmer 2004). The effector HopPtoC (EAMY_0744) is an ortholog of the secreted papain-like cysteine proteases YopT in Yersinia spp. (Grant et al. 2006) and HopC1 in P. syringae pv. tomato DC3000 (Buell et al. 2003). The effector encoded by EAMY_3175 is homologous to AvrRpt2, another cysteine protease (Grant et al. 2006), which renders virulent strains of $P$. syringae avirulent on selected lines of Arabidopsis thaliana, Glycine max, and Phaseolus vulgaris (Innes et al. 1993). The protein is cleaved and activated upon entry in the eukaryotic cell (Jin et al. 2003). In E. amylovora, avrRpt 2 contributes to the ability of the pathogen to infect immature pear fruit (Zhao et al. 2006).

\section{Flagellar genes.}

Two sets of genes encoding flagellar biosynthesis and chemotaxis-related proteins were found in the genome of $E$. amylovora CFBP 1430. One set is tightly clustered (EAMY 2647-EAMY_2702) and matches an analogous region found in E. pyrifoliae DSM $12163^{\mathrm{T}}$ (Smits et al. 2010) but is absent in E. tasmaniensis Et1/99 (Kube et al. 2008). This also explains the absence of the quorum-sensing genes expRI in $E$. amylovora CFBP 1430 and E. pyrifoliae DSM $12163^{\mathrm{T}}$ which are present in E. tasmaniensis Et1/99, in the region between smpB (ETA_09720) and tsx (ETA_09440). The latter two genes flank the insertion site of the flagellar gene cluster in E. amylovora CFBP 1430 and E. pyrifoliae DSM $12163^{\mathrm{T}}$, revealing the gene replacement that occurred in the latter two species. Furthermore, with respect to E. amylovora CFBP 1430 , the region upstream of this flagellar gene cluster differs in E. pyrifoliae DSM $12163^{\mathrm{T}}$, where the insertion of a low$\mathrm{G}+\mathrm{C}$ genomic island (EPYR_1033-1040) between the $s m p B$ and $k p s C$ is obvious. This would suggest that, during the evolution from the last common Erwinia progenitor to E. pyrifo-

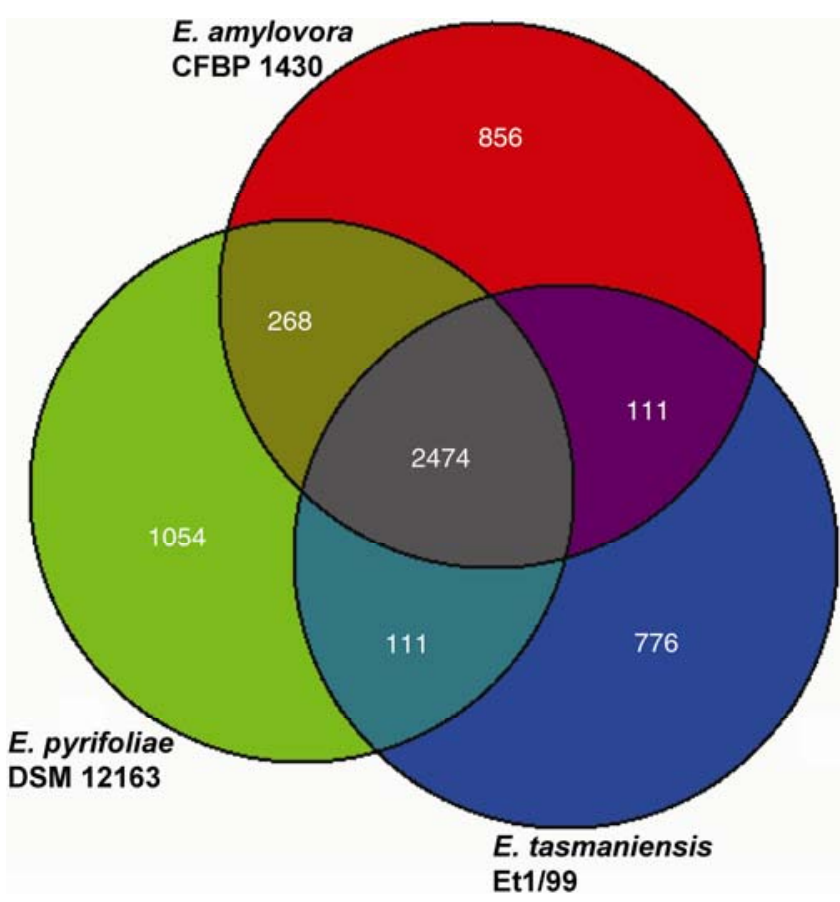

Fig. 4. Venn diagram generated with EDGAR representing the pan genome of Erwinia amylovora CFBP 1430, E. pyrifoliae DSM $12163^{\mathrm{T}}$, and E. tasmaniensis Et1/99. 
liae, two distinct insertion events have taken place at this hot spot.

A second complete set of flagellar genes, which closely resembles those found in E. tasmaniensis Et1/99 and E. pyrifoliae DSM $12163^{\mathrm{T}}$, is split in different clusters throughout the genome of E. amylovora CFBP 1430 (EAMY_1450-EAMY_ 1463, EAMY_1499-EAMY_1515, EAMY_2083-EAMY_2100, and EAMY_2138-EAMY_2144). Compared with the other flagellar assembly apparatus, this second gene cluster appears to be ancestral in the genus Erwinia and contains two extra genes encoding FliZ (EAMY_2138), a putative alternative sigma factor regulatory protein, and CheV (EAMY_1515), a hypothetical chemotaxis signal transduction protein, respectively.

\section{Exopolysaccharide biosynthesis.}

Two different exopolysaccharides (EPS), amylovoran and levan, are produced by E. amylovora. E. pyrifoliae DSM $12163^{\mathrm{T}}$ only produces amylovoran (Kim et al. 2002), whereas E. tasmaniensis Et1/99 does not produce either type of EPS (Kube et al. 2008). Two genes, $a m s D$ and $a m s E$ (EAMY_2247-EAMY_2246), of the amylovoran biosynthetic gene cluster (EAMY_2253-EAMY_2241) encoding glycosyltransferases, are only shared in E. amylovora CFBP 1430 and E. pyrifoliae DSM $12163^{\mathrm{T}}$ (Smits et al. 2010). This is in agreement with previous reports (Kube et al. 2008; Smits et al. 2010), indicating that the E. tasmaniensis Et1/99 EPS cluster is more similar to the stewartan biosynthetic cluster of Pantoea stewartii subsp. stewartii DC283 (Coplin et al. 1996). The gene encoding levansucrase (EAMY_3695), responsible for the biosynthesis of levan (Gross et al. 1992), is absent from $E$. pyrifoliae DSM $12163^{\mathrm{T}}$ (Smits et al. 2010) but present in the other species.

\section{Type I secretion.}

The type I secretion system prtADEF encodes an excreted protease (PrtA) and its export system (PrtDEF) plays a minor role at most in the virulence of $E$. amylovora (Zhang et al. 1999). The prtADEF system is only present in the genome of E. amylovora CFBP 1430 (EAMY_3577-EAMY_3581) but not in the other species. For E. tasmaniensis Et1/99, the lack of this system was interpreted to be one factor in the lack of virulence on pome fruit trees of this strain (Kube et al. 2008) but its absence in the related fire blight pathogen E. pyrifoliae DSM $12163^{\mathrm{T}}$ suggests it may be a specific contributor to hostrange virulence in E. amylovora rather than an absolute virulence determinant.

\section{Type II secretion.}

A type II secretion system (outCDEFFHJKLMNOS-chiV; EAMY_2865-EAMY_2878) (T2SS), induced during an immature pear assay (Zhao et al. 2005), was found in the genomes of all three Erwinia strains, including the nonpathogen E. tasmaniensis, indicating that it may not be a virulence factor. Indeed, mutational analysis with E. amylovora Ea1189 has demonstrated that this T2SS system has no role in pathogenicity on immature pear or apple seedlings (Zhao et al. 2009). The presence of a chitin-binding domain (pfam03067) in the putative ChiV protein (EAMY_2873) suggests that the T2SS system may contribute to a yet-to-be-identified interaction with insect vectors of $E$. amylovora CFBP 1430.

\section{Type VI secretion.}

Three type VI secretion system (T6SS) gene clusters were identified in E. amylovora CFBP 1430. They differ in composition and organization of core and hypothetical genes. T6SS clusters 1 (EAMY_3028-EAMY_3000) and 2 (EAMY_1623EAMY_1620) of $\bar{E}$. amylovora $\overline{C F B P}_{1430}$ are highly similar to the T6SS cluster of E. pyrifoliae DSM $12163^{\mathrm{T}}$ and E. tasmaniensis Et1/99 (Smits et al. 2010), whereas T6SS cluster 3 (EAMY_3228-EAMY_3201) is absent in both E. pyrifoliae DSM $12163^{\mathrm{T}}$ and E. tasmaniensis Et1/99.

The first T6SS cluster of E. amylovora CFBP 1430 is composed of 27 genes (Supplementary Fig. 2), of which 15 genes were identified as T6SS-core genes (3 putative effectors and 2 putative signal transducers), 4 were identified as conserved genes between species, and 6 as hypothetical genes. In T6SS clusters 1 and 2, blocks of conserved genes between bacterial species are observed, interspaced by hypothetical genes. The first T6SS cluster of E. amylovora CFBP 1430 is organized similarly to the T6SS cluster of E. pyrifoliae DSM $12163^{\mathrm{T}}$ and E. tasmaniensis Et1/99, with three critical differences: the genes between DUF877 and COG3456 as well as the genes between vgrGl and vgrG2 differ and E. pyrifoliae DSM $12163^{\mathrm{T}}$ and $E$. tasmaniensis Et1/99 have two additional genes between COG3520 and $c l p V$. Three hypothetical genes in E. amylovora CFBP 1430 (EAMY_3015, EAMY_3001, and EAMY_3002) and E. pyrifoliae DSM 12163 ${ }^{\mathrm{T}}$ (EPYR_00659, EPYR_00672, and EPYR_00673) are observed which are absent in E. tasmaniensis Et1/99. E. amylovora CFBP 1430 and E. tasmaniensis Et1/99 share two hypothetical genes (EAMY_3017-EAMY 3018 and ETA_06210-ETA_6230) which are absent in E. pyrifoliae DSM $12163^{\mathrm{T}}$. In T6SS cluster 2 of E. amylovora CFBP 1430 , three core genes and one conserved gene were identified. The proteins encoded by this cluster show higher similarities to the corresponding proteins of E. pyrifoliae DSM $12163^{\mathrm{T}}$ than to E. tasmaniensis Et1/99.

The third T6SS cluster was identified only in E. amylovora CFBP 1430. This cluster is located within a putative genomic island and, therefore, might be acquired by horizontal gene transfer. This cluster consists of 31 genes, 15 genes of which were identified as core genes (three putative effectors) and 16 as hypothetical genes. Putative signal transducers are not present. The cluster differs significantly in gene composition and organization from T6SS cluster 1 . The proteins encoded in T6SS cluster 3 have only low sequence identities compared with the corresponding proteins of T6SS cluster 1.

\section{Quorum-sensing elements.}

Two main quorum-sensing systems are known in gramnegative bacteria and are defined by the chemical structure of the autoinducer (AI) signal molecule involved (Miller and Bassler 2001). For both systems, the gene endowment of $E$. amylovora is analogous to the one found in E. pyrifoliae DSM $12163^{\mathrm{T}}$ (Smits et al. 2010) and E. tasmaniensis Et1/99 (Kube et al. 2008).

The protein encoded by gene EAMY_1412 shows $45 \%$ identity with the DNA-binding transcriptional activator SdiA that controls cell division in Escherichia coli and Salmonella typhimurium (Wang et al. 1991), and which responds to AI-1 signals (i.e., AHL) generated by other microbial species. Similar to the situation found in E. coli and S. typhimurium (Michael et al. 2001), Erwinia amylovora lacks a corresponding signalgenerating enzyme. This contradicts previous reports for AHLsignaling in E. amylovora (Venturi et al. 2004; Molina et al. 2005). Nearby gene EAMY_1411 has low sequence identity (29\%) with the AI-1 synthesis protein PhzI of Pseudomonas chlororaphis. Thus, the E. amylovora gene set composed by EAMY_1411 and EAMY_1412 either may function in the production and detection of a yet-unknown extracellular signal (not necessarily related to known AI molecules) or EAMY_1412 may be an orphan receptor utilized by E. amylovora to eavesdrop on quorum-sensing signals of other organisms. Such functions would explain observations of AHL-biosensor cross-feeding by E. amylovora. 
The luxS gene (EAMY_0812), which is the central component implicated in the generation of the AI-2 quorum-sensing signal, was located in E. amylovora CFBP 1430. However, the essential accessory genes involved in signal response (Taga et al. 2003; Reading and Sperandio 2006; Rezzonico and Duffy 2008) are lacking. Without these, despite a weak signaling activity observed using biosensors (Rezzonico and Duffy 2007), the function of LuxS in E. amylovora CFBP 1430 must be restricted to its metabolic role of enzyme involved in the activated methyl cycle (Winzer et al. 2003; Rezzonico and Duffy 2008).

\section{Iron uptake determinants.}

Iron is an essential nutritional factor for every living organism, as a cofactor for numerous proteins. The regulation of iron uptake in bacteria is under control of global regulation by the ferric uptake receptor Fur, which specifically regulates biosynthesis and uptake of iron-affinity siderophores (Hantke 1981; de Lorenzo et al. 1987; Dellagi et al. 1998). The fur gene (EAMY_1148) is found in all three Erwinia spp. (Supplementary Table 3).

E. amylovora is known to produce only the hydroxamate siderophore desferrioxamine E (DFO E) (Feistner et al. 1993; Kachadourian et al. 1996) and a transposon mutant within the biosynthetic gene $d f o A$ is strongly affected in its ability to colonize the flowers of apple trees as well as in its ability to initiate necrosis, leading to a lower level of virulence (Dellagi et al. 1998). The biosynthetic genes for desferrioxamine $\mathrm{E}$ were recently identified in E. pyrifoliae DSM $12163^{\mathrm{T}}$ (Smits et al. 2010) and orthologs for all of these are present in E. amylovora CFBP 1430 (EAMY_3238 to EAMY_3240) and E. tasmaniensis Et1/99. Despite prior efforts (Expert 1999; Expert et al. 2000), the $d$ foJAC gene cluster identified from the genome sequence only now reveals first insights into the biosynthetic pathway of DFO in E. amylovora CFBP 1430, that is essentially similar to the DFO biosynthesis pathway of Streptomyces coelicolor $\mathrm{A} 3(2)$ (Challis 2005).

Resorption of iron (III)-loaded siderophores requires a TonB-dependent receptor that transports the siderophores into the periplasmic space. The genome of $E$. amylovora CFBP 1430 contains four TonB-dependent receptors. One encodes a putative copper receptor OprC (EAMY_1821). A second encodes the ferrioxamine receptor FoxR (EAMY_3241) (Kachadourian et al. 1996; Dellagi et al. 1998). A third and fourth are previously unknown TonB-dependent receptors that cannot be classified completely by the TCDB system (EAMY_1761 and EAMY_1080). With the exception of one of the unclassified receptors that is inactivated in E. pyrifoliae DSM $12163^{\mathrm{T}}$ (Smits et al. 2010), all are shared by E. pyrifoliae DSM $12163^{\mathrm{T}}$ and E. tasmaniensis Et1/99.

In the genome of E. amylovora CFBP 1430, there are remnants present for two further TonB-dependent receptors. One encodes the ferrichrome receptor FhuA, for which intact orthologs exist in E. pyrifoliae DSM $12163^{\mathrm{T}}$ and E. tasmaniensis Et1/99, and one encodes the ferric aerobactin receptor IutA, that is absent from the other two strains. The genome of E. tasmaniensis Et1/99 encodes two additional TonB-dependent receptors, of which one is the ferric dicitrate receptor FecA (Kube et al. 2008). For both receptors, ABC transporters, necessary for the uptake of iron over the cytoplasmic membrane, are present as well. The genome of E. amylovora CFBP 1430 contains only three iron-uptake $\mathrm{ABC}$ transport systems (fhuCDB, hmuSTUV, and sitABCD), all shared by E. pyrifoliae DSM $12163^{\mathrm{T}}$ and E. tasmaniensis Et1/99.

The limited genetic basis for iron uptake in E. amylovora CFBP 1430 is also reflected by a limited utilization of iron siderophores by this organism (Kachadourian et al. 1996). The fact that ferric dicitrate is not utilized is confirmed by the absence of the complete $f e c$ system, whereas the inactivation of $f h u A$ will abolish ferrichrome uptake. In contrast to Pectobacterium atrosepticum SCRI 1043 (Bell et al. 2004), all sequenced Erwinia spp. do not contain the biosynthetic cluster for enterobactin, the catecholate siderophore produced by many enteric pathogens.

\section{Conclusions.}

Comparison of all three currently sequenced Erwinia genomes has revealed several interesting features that may explain observed phenotypical differences between the species. Although many of the virulence factors found in E. amylovora (Oh and Beer 2005) are present in the genomes of one or both of the other species, our comparative analysis demonstrated that a number are specific for E. amylovora and, therefore, may contribute to the broad-spectrum and severe-disease phenotype of this species. Our analysis of these Erwinia genomes raises questions concerning host range, virulence, and other host interactions. Currently, the major factors considered critical for pathogenicity or virulence on Rosaceous hosts are the Hrp T3SS-related genes and amylovoran biosynthesis (Bernhard et al. 1996; Oh and Beer 2005; Oh et al. 2005; Zhao et al. 2009). Our comparative genomic analysis indicates that E. amylovora and $E$. pyrifoliae share a basic repertoire of virulence factors. Their genetic similarity, causation of essentially indistinguishable symptoms, and reported E. pyrifoliae pathogenicity on apple (Malus domestica) and pear (Pyrus communis) cultivars as well as Asian pear (P. pyrifolia) (Duffy and Dandekar 2008; Kim et al. 2001) justify reference to both species as fire blight pathogens, despite their different host range and virulence and without minimizing the higher phytosanitary relevance of $E$. amylovora.

Potentially, new virulence-related factors were revealed in $E$. amylovora CFBP 1430, the closely related pathogen E. pyrifoliae DSM $12163^{\mathrm{T}}$, and the presumably nonpathogenic E. tasmaniensis Et1/99. The two T3SSs on genomic islands PAI-2 and PAI-3 have high homology with the insect pathogen Sodalis glossinidus str. morsidans and to the mammalian pathogens Salmonella and Yersinia spp. (Zhao et al. 2009). A novel gene encoding a protein with a chitinase-binding domain was found directly downstream of the T2SS in E. amylovora CFBP 1430 (chiV; EAMY_2878). E. amylovora CFBP 1430 and E. pyrifoliae DSM $12163^{\mathrm{T}}$ chromosomes both have genes annotated as $\beta$ hexosaminidase (EAMY_0363 and EPYR_00390, respectively), and two plasmids of E. pyrifoliae DSM $12163^{\mathrm{T}}$ encode downstream of the $h c p$ genes a putative endochitinase (EPYR_04028 and EPYR_04035) (Smits et al. 2010), absent in E. amylovora CFBP 1430. This suggests a possibly closer insect association beyond the passive dispersal known to be critical in fire blight epidemiology (Johnson and Stockwell 1998).

Comparison of our complete genome for E. amylovora CFBP 1430 with that of E. amylovora Ea273 confirmed the high genetic-homogeneity observed within this species $(>99.99 \%)$. This level of conservation between a European and U.S. strain reflects the relatively recent dispersal of the species and indicates a low rate of significant evolution. However, our analysis revealed a major genomic reorganization, with two inversions of large genomic regions based on crossovers in two different 16S rRNA operons. These reorganizations explain the different PFGE patterns observed in these and perhaps other genotypes (Zhang and Geider 1997; Jock et al. 2002). The physiological role of this genomic reorganization remains to be examined in more detail using different strains having different PFGE patterns.

Novel insights from the genome of E. amylovora CFBP 1430 such as the identification of the T6SSs, the NPRS, and 
the PKS cluster (Supplementary information) warrant evaluation of the role of these systems in the virulence, host range, or ecological behavior of E. amylovora on Rosaceous plants. This and, particularly, potential new determinants of pathogen-insect interactions may facilitate design of more effective control strategies against fire blight.

\section{MATERIALS AND METHODS}

\section{Whole-genome sequencing.}

Genomic DNA of an early European isolate of E. amylovora (CFBP 1430, France, 1972, Crataegus) was isolated using the Wizard Genomic DNA Purification Kit (Promega Corp., Madison, WI, U.S.A.). Whole-genome sequencing was performed by GATC (Konstanz, Germany) using an Illumina sequencer. In total, 4,469,394 high-quality filtered sequence reads were generated, with an average 36-bp read length and an average coverage equivalent to $42 \times$. Quality filtered sequences were aligned to the draft genome sequence of the U.S. strain $E$. amylovora Ea273, available as a fasta file at the Sanger center (Bocsanczy et al. 2008) using the program NGen (DNASTAR, Madison, WI, U.S.A.) and were manually checked for inconsistencies. All reads were additionally de novo assembled using the program EDENA (Hernandez et al. 2008) with manually optimized settings. This yielded 2,627 contigs $\left(\mathrm{N}_{50}=2,617\right.$, mean length $=1,399$, maximum length $=12,053$, minimum length $=100)$. The assembled contigs were aligned to the sequence using the LASERGENE package (DNASTAR). Differences and large gaps were manually checked against the original assembly. Additionally, the reads that were not included in the initial assembly were assembled as well using EDENA using a 60-bp minimal fragment size yielding two fragments of 645 and $91 \mathrm{bp}$, respectively.

Based on identified differences between the CFBP 1430 and Ea273 genome sequences and areas with known sequence variation, several regions were checked by PCR using standard conditions (Innis et al. 1990) and sequenced using the Sanger method on a 3130XL sequencer (Applied Biosystems, Rotkreuz, Switzerland). Final assembly was done using the LASERGENE package. The rRNA operons were covered by PCR fragments amplified from primers in both flanks of the rRNA regions, and completely sequenced.

\section{Genome annotation.}

Genes were predicted using a combined strategy (McHardy et al. 2004) based on the CDS prediction programs Glimmer (Salzberg et al. 1998) and Critica (Badger and Olsen 1999). Subsequently, the potential function of each predicted gene was automatically assigned using the GenDB annotation pipeline (Meyer et al. 2003). The resulting genome annotation was manually curated, and metabolic pathways were identified using the KEGG pathways tool (Kanehisa et al. 2002) in GenDB.

\section{Comparative analysis.}

The genome sequences of three ecologically distinct Erwinia spp. were compared to identify the set of common genes composing the core genome for this genus and the set of genes unique to each species, referred to as singletons. For this purpose, an "all-against-all" comparison of the genes was accomplished using the BLAST alignment tool (Altschul et al. 1990). The genes were aligned based on the protein sequence (BLASTP) with an initial $e$-value cut-off of $1 \mathrm{E}-5$ using the BLOSUM62 scoring matrix. Genes were considered orthologous when a reciprocal best BLAST hit was found between two genes, and when both BLAST hits were based on alignments exceeding $70 \%$ sequence identity spanning over at least $70 \%$ of the query gene length (Blom et al. 2009). The Erwinia genus core genome was calculated as the set of genes of a reference strain for which an orthologous gene could be found in each of the compared genomes. In contrast, genes of one strain were considered to be singleton genes when they had no BLAST-hits comparability with any of the other genomes that satisfied the given criteria. A Venn diagram was created using the plotting routines of EDGAR (Blom et al. 2009). Synteny plots were generated as alignments of the complete genome nucleotide sequences using MUMMER 3.0 (Kurtz et al. 2004).

\section{Additional analysis.}

Routine sequence manipulations were completed using several subroutines of the LASERGENE package. Comparative analysis of the genome sequences of E. amylovora CFBP 1430, E. pyrifoliae DSM $12163^{\mathrm{T}}$, and E. tasmaniensis Et1/99 was performed using MAUVE (Darling et al. 2004) in the standard and progressive mode.

\section{ACKNOWLEDGMENTS}

We thank B. Frey, T. Dreo, and C. Pelludat for exemplary technical support throughout this project. This work was supported by the Swiss Federal Office for Agriculture (BLW Fire Blight Research-Pathogen) and the Swiss Secretariat for Education and Research (SBF C07.0038). It was conducted within the European Science Foundation funded research network COST Action FA864.

\section{LITERATURE CITED}

Alfano, J. R., and Collmer, A. 2004. Type III secretion system effector proteins: Double agents in bacterial disease and plant defence. Annu. Rev. Phytopathol. 42:385-414.

Altschul, S. F., Gish, W., Miller, W., Myers, E. W., and Lipman, D. J. 1990. Basic local alignment search tool. J. Mol. Biol. 215:403-410.

Badger, J. H., and Olsen, G. J. 1999. CRITICA: Coding region identification tool invoking comparative analysis. Mol. Biol. Evol. 16:512-524.

Bell, K. S., Sebaihia, M., Pritchard, L., Holden, M. T. G., Hyman, L. J., Holeva, M. C., Thomson, N. R., Bentley, S. D., Churcher, L. J. C., Mungall, K., Atkin, R., Bason, N., Brooks, K., Chillingworth, T., Clark, K., Doggett, J., Fraser, A., Hance, Z., Hauser, H., Jagels, K., Moule, S., Norbertczak, H., Ormond, D., Price, C., Quail, M. A., Sanders, M., Walker, D., Whitehead, S., Salmond, G. P. C., Birch, P. J. R., Parkhill, J., and Toth, I. K. 2004. Genome sequence of the enterobacterial phytopathogen Erwinia carotovora subsp. atroseptica and characterization of virulence factors. Proc. Natl. Acad. Sci. U.S.A. 101:11105-11110.

Bernhard, F., Schullerus, D., Bellemann, P., Geider, K., Nimtz, M., Majerczak, D. R., and Coplin, D. L. 1996. Genetics and complementation of DNA regions involved in amylovoran synthesis of Erwinia amylovora and stewartan synthesis of Erwinia stewartii. Acta Hortic. 411:269-274.

Blom, J., Albaum, S. P., Doppmeier, D., Pühler, A., Vorhölter, F.-J., Zakrzewski, M., and Goesmann, A. 2009. EDGAR: A software framework for the comparative analysis of prokaryotic genomes. BMC Bioinformatics 10:154.

Bocsanczy, A. M., Beer, S. V., Perna, N. T., Biehl, B., Glasner, J. D., Cartinhour, S. W., Schneider, D. J., DeClerck, G. A., Sebaihia, M. Parkhill, J., and Bentley, S. 2008. Contributions of the genome sequence of Erwinia amylovora to the fire blight community. Acta Hortic. 793:163-170.

Bonn, W. G., and van der Zwet, T. 2000. Distribution and economic importance of fire blight. Pages 37-53 in: Fire Blight: The Disease and Its Causative Agent, Erwinia amylovora. J. L. Vanneste, ed. CAB International, Wallingford, U.K.

Boureau, T., El Maarouf-Bouteau, H., Garnier, A., Brisset, M.-N., Perino, C., Pucheu, I., and Barny, M.-A. 2006. DspA/E, a type III effector essential for Erwinia amylovora pathogenicity and growth in planta, induces cell death in host apple and nonhost tobacco plants. Mol. PlantMicrobe Interact. 19:16-24.

Buell, C. R., Joardar, V., Lindeberg, M., Selengut, J., Paulsen, I. T., Gwinn, M. L., Dodson, R. J., Deboy, R. T., Durkin, A. S., Kolonay, J. F., Madupu, R., Daugherty, S., Brinkac, L., Beanan, M.J., Haft, D. H., Nelson, W. C., Davidsen, T., Zafar, N., Zhou, L., Liu, J., Yuan, Q., Khouri, H., Fedorova, N., Tran, B., Russell, D., Berry, K., Utterback, T., Van Aken, S. E., Feldblyum, T. V., D’Ascenzo, M., Deng, W.-L., Ramos, A. R., Alfano, J. R., Cartinhour, S., Chatterjee, A. K., Delaney, T. P., Lazarowitz, S. G., 
Martin, G. B., Schneider, D. J., Tang, X., Bender, C. L., White, O., Fraser, C. M., and Collmer, A. 2003. The complete genome sequence of the Arabidopsis and tomato pathogen Pseudomonas syringae pv. tomato DC3000. Proc. Natl. Acad. Sci. U.S.A. 100:10181-10186.

Calvin, L., and Krissoff, B. 1998. Technical barriers to trade: A case study of phytosanitary barriers and U.S.-Japanese apple trade. J. Agric. Res. Econom. 23:351-366

Challis, G. L. 2005. A widely distributed bacterial pathway for siderophore biosynthesis independent of nonribosomal peptide synthetases. Chembiochem 6:601-611.

Chang, J. H., Urbach, J. M., Law, T. F., Arnold, L. W., Hu, A., Gombar, S., Grant, S. R., Ausubel, F. M., and Dangl, J. L. 2005. A high-throughput near-saturating screen for type III effector genes from Pseudomonas syringae. Proc. Natl. Acad. Sci. U.S.A. 102:2549-2554.

Coplin, D. L., Majerczak, D. R., Bugert, P., and Geider, K. 1996. Nucleotide sequence analysis of the Erwinia stewartii cps gene cluster for synthesis of stewartan and comparison to the Erwinia amylovora ams cluster for synthesis of amylovoran. Acta Hortic. 411:251-257.

Dale, C., Young, S. A., Haydon, D. T., and Welburn, S. C. 2001. The insect endosymbiont Sodalis glossinidius utilizes a type III secretion system for cell invasion. Proc. Natl. Acad. Sci. U.S.A. 98:1883-1888.

Darling, A. C. E., Mau, B., Blattner, F. R., and Perna, N. T. 2004. Mauve: Multiple alignment of conserved genomic sequence with rearrangements. Genome Res. 14:1394-1403.

Dellagi, A., Brisset, M.-N., Paulin, J.-P., and Expert, D. 1998. Dual role of desferrioxamine in Erwinia amylovora pathogenicity. Mol. Plant-Microbe Interact. 11:734-742

de Lorenzo, V., Wee, S., Herrero, M., and Neilands, J. B. 1987. Operator sequences of the aerobactin operon of plasmid ColV-K30: Binding of the ferric uptake regulation (fur) repressor. J. Bacteriol. 169:2624-2630.

Duffy, B., and Dandekar, A. M. 2008. Sorbitol has no role in fire blight as demonstrated using transgenic apple with constitutively altered content. Acta Hortic. 793:279-283.

Duffy, B., Schärer, H.-J., Bünter, M., Klay, A., and Holliger, E. 2005. Regulatory measures against Erwinia amylovora in Switzerland. EPPO Bull. 35:239-244

Expert, D. 1999. Withholding and exchanging iron: Interactions between Erwinia spp. and their host plants. Annu. Rev. Phytopathol. 37:307-334.

Expert, D., Dellagi, A., and Kachadourian, R. 2000. Iron and fire blight: Role in pathogenicity of desferrioxamine $\mathrm{E}$, the main siderophore of Erwinia amylovora. Pages 179-195 in: Fire Blight: The Disease and Its Causative Agent, Erwinia amylovora. J. L. Vanneste, ed. CAB International, Wallingford, U.K.

Feistner, G. J., Stahl, D. C., and Gabrik, A. H. 1993. Proferrioxamine siderophores of Erwinia amylovora. A capillary liquid chromatographic/ electrospray tandem mass spectrometry study. Org. Mass Spectrom. $28: 163-175$

Foster, G. C., McGhee, G. C., Jones, A. L., and Sundin, G. W. 2004. Nucleotide sequences, genetic organization, and distribution of pEU30 and pEL60 from Erwinia amylovora. Appl. Environ. Microbiol. 70:75397544.

Gaudriault, S., Malandrin, L., Paulin, J.-P., and Barny, M.-A. 1997. DspA, an essential pathogenicity factor of Erwinia amylovora showing homology with AvrE of Pseudomonas syringae, is secreted via the Hrp secretion pathway in a DspB-dependent way. Mol. Microbiol. 26:1057-1069.

Grant, S. R., Fisher, E. J., Chang, J. H., Mole, B. M., and Dangl, J. L. 2006. Subterfuge and manipulation: Type III effector proteins of phytopathogenic bacteria. Annu. Rev. Microbiol. 60:425-449.

Grissa, I., Vergnaud, G., and Pourcel, C. 2007. CRISPRFinder: A web tool to identify clustered regularly interspaced short palindromic repeats. Nucleic Acids Res. 35:W52-57.

Gross, M., Geier, G., Rudolph, K., and Geider, K. 1992. Levan and levansucrase synthesized by the fireblight pathogen Erwinia amylovora. Physiol. Mol. Plant Pathol. 40:371-381

Haft, D. H., Selengut, J., Mongodin, E. F., and Nelson, K. E. 2005. A guild of 45 CRISPR-associated (Cas) protein families and multiple CRISPR/Cas subtypes exist in prokaryotic genomes. PLoS Comp. Biol. $1: e 60$

Halbwirth, H., Fischer, T. C., Roemmelt, S., Spinelli, F., Schlangen, K., Peterek, S., Sabatini, E., Messina, C., Speakman, J.-B., Andreotti, C., Rademacher, W., Bazzi, C., Costa, G., Treutter, D., Formkann, G., and Stich, K. 2003. Induction of antimicrobial 3-deoxyflavonoids in pome fruit trees controls fire blight. Z. Naturforsch. 58c:765-770.

Hantke, K. 1981. Regulation of ferric iron transport in Escherichia coli K12: Isolation of a constitutive mutant. Mol. Gen. Genet. 182:288-292.

He, S. Y., Nomura, K., and Whittam, T. S. 2004. Type III protein secretion mechanism in mammalian and plant pathogens. Biochim. Biophys. Acta 1694:181-206.

Hernandez, D., François, P., Farinelli, L., Østerås, M., and Schrenzel, J. 2008. De novo bacterial genome sequencing: Millions of very short reads assembled on a desktop computer. Genome Res. 18:802-809.

Innes, R. W., Bent, A. F., Kunkel, B. N., Bisgrove, S. R., and Staskawicz, B. J. 1993. Molecular analysis of avirulence gene avrRpt2 and identification of a putative regulatory sequence common to all known Pseudomonas syringae avirulence genes. J. Bacteriol. 175:4859-4869.

Innis, M. A., Gelfand, D. H., Sninsky, J. J., and White, T. J. 1990. PCR Protocols. A Guide to Methods and Applications. Academic Press, Inc., San Diego, CA, U.S.A.

Jin, P., Wood, M. D., Wu, Y., Xie, Z., and Katagiri, F. 2003. Cleavage of the Pseudomonas syringae type III effector AvrRpt2 requires a host factor(s) common among Eukaryotes and is important for AvrRpt2 localization in the host cell. Plant Physiol. 133:1072-1082.

Jock, S., Donat, V., López, M. M., Bazzi, C., and Geider, K. 2002. Following spread of fire blight in Western, Central and Southern Europe by molecular differentiation of Erwinia amylovora strains with PFGE analysis. Environ. Microbiol. 4:106-114.

Johnson, K. B., and Stockwell, V. O. 1998. Management of fire blight: A case study in microbial ecology. Annu. Rev. Phytopathol. 36:227-248.

Kachadourian, R., Dellagi, A., Laurent, J., Bricard, L., Kunesch, G., and Expert, D. 1996. Desferrioxamine-dependent iron transport in Erwinia amylovora CFBP 1430: Cloning of the gene encoding the ferrioxamine receptor FoxR. BioMetals 9:143-150.

Kanehisa, M., Goto, S., Kawashima, S., and Nakaya, A. 2002. The KEGG databases at GenomeNet. Nucleic Acids Res. 30:42-46.

Kim, W.-S., and Geider, K. 1999. Analysis of variable short-sequence DNA repeats on the $29 \mathrm{~kb}$ plasmid of Erwinia amylovora strains. Eur. J. Plant Pathol. 105:703-713.

Kim, W.-S., Jock, S., Paulin, J.-P., Rhim, S.-L., and Geider, K. 2001. Molecular detection and differentiation of Erwinia pyrifoliae and host range analysis of the Asian pear pathogen. Plant Dis. 85:1183-1188.

Kim, W.-S., Schollmeyer, M., Nimtz, M., Wray, V., and Geider, K. 2002. Genetics of biosynthesis and structure of the capsular exopolysaccharide from the Asian pear pathogen Erwinia pyrifoliae. Microbiology 148:4015-4024.

Kube, M., Migdoll, A. M., Müller, I., Kuhl, H., Beck, A., Reinhardt, R., and Geider, K. 2008. The genome of Erwinia tasmaniensis strain Et1/99, a non-pathogenic bacterium in the genus Erwinia. Environ. Microbiol. 10:2211-2222.

Kurtz, S., Phillippy, A., Delcher, A. L., Smoot, M., Shumway, M., Antonescu, C., and Salzberg, S. L. 2004. Versatile and open software for comparing large genomes. Genome Biol. 5:r12.

Llop, P., Bonaterra, A., Peñalver, J., and López, M. M. 2000. Development of a highly sensitive nested-PCR procedure using a single closed tube for detection of Erwinia amylovora in asymptomatic plant material. Appl. Environ. Microbiol. 66:2071-2078.

Llop, P., Donat, V., Rodríguez, M., Cabrefiga, J., Ruz, L., Palomo, J. L., Montesinos, E., and López, M. M. 2006. An indigenous virulent strain of Erwinia amylovora lacking the ubiquitous plasmid pEa29. Phytopathology 96:900-907.

Llop, P., López, M. M., Cabrefiga, J., Ruz, L., and Montesinos, E. 2008. Study of the virulence in wild-type strains of Erwinia amylovora devoid of the plasmid pEa29. Acta Hortic. 793:145-148.

Makarova, K. S., Grishin, N. V., Shabalina, S., Wolf, Y. I., and Koonin, E. V. 2006. A putative RNA-interference-based immune system in prokaryotes: Computational analysis of the predicted enzymatic machinery, functional analogies with eukaryotic RNAi, and hypothetical mechanisms of action. Biol. Direct 1:7.

McClelland, M., Sanderson, K. E., Spieth, J., Clifton, S. W., Latreille, P., Courtney, L., Porwollik, S., Ali, J., Dante, M., Du, F., Hou, S., Layman, D., Leonard, S., Nguyen, C., Scott, K., Holmes, A., Grewal, N., Mulvaney, E., Ryan, E., Sun, H., Florea, L., Miller, W., Stoneking, T., Nhan, M., Waterston, R., and Wilson, R. K. 2001. Complete genome sequence of Salmonella enterica serovar Typhimurium LT2. Nature 413:852-856

McGhee, G. C., and Jones, A. L. 2000. Complete nucleotide sequence of ubiquitous plasmid pEa29 from Erwinia amylovora strain Ea88: Gene organization and intraspecies variation. Appl. Environ. Microbiol. 66:4897-4907.

McGhee, G. C., and Sundin, G. W. 2008. Thiamin biosynthesis and its influence on exopolysaccharide production: A new component of virulence identified on Erwinia amylovora plasmid pEa29. Acta Hortic. 793:271-277

McGhee, G. C., Schnabel, E. L., Maxson-Stein, K., Jones, B., Stromberg, V. K., Lacy, G. H., and Jones, A. L. 2002. Relatedness of chromosoma and plasmid DNAs of Erwinia pyrifoliae and Erwinia amylovora. Appl. Environ. Microbiol. 68:6182-6192.

McHardy, A. C., Goesmann, A., Pühler, A., and Meyer, F. 2004. Development of joint application strategies for two microbial gene finders. Bioinformatics 20:1622-1631.

McManus, P. S., Stockwell, V. O., Sundin, G. W., and Jones, A. L. 2002. 
Antibiotic use in plant agriculture. Annu. Rev. Phytopathol. 40:443-465.

Meyer, F., Goesmann, A., McHardy, A. C., Bartels, D., Bekel, T., Clausen, J., Kalinowski, J., Linke, B., Rupp, O., Giegerich, R., and Pühler, A. 2003. GenDB - an open source genome annotation system for prokaryote genomes. Nucleic Acids Res. 31:2187-2195.

Michael, B., Smith, J. N., Swift, S., Heffron, F., and Ahmer, B. M. M 2001. SdiA of Salmonella enterica is a LuxR homolog that detects mixed microbial communities. J. Bacteriol. 183:5733-5742.

Miller, M. B., and Bassler, B. L. 2001. Quorum sensing in bacteria. Annu. Rev. Microbiol. 55:165-199.

Mojica, F. J. M., Díez-Villaseñor, C., García-Martínez, J., and Soria, E. 2005. Intervening sequences of regularly spaced prokaryotic repeats derive from foreign genetic elements. J. Mol. Evol. 60:174-182.

Molina, L., Rezzonico, F., Défago, G., and Duffy, B. 2005. Autoinduction in Erwinia amylovora: Evidence of an acyl-homoserine lactone signal in the fire blight pathogen. J. Bacteriol. 187:3206-3213.

Nissinen, R. M., Ytterberg, A. J., Bogdanove, A. J., Van Wijk, K. J., and Beer, S. V. 2007. Analyses of the secretomes of Erwinia amylovora and selected hrp mutants reveal novel type III secreted proteins and an effect of HrpJ on extracellular harpin levels. Mol. Plant Pathol. 8:55-67.

Norelli, J. L., Jones, A. L., and Aldwinckle, H. S. 2003. Fire blight management in the twenty-first century: Using new technologies that enhance host resistance in apple. Plant Dis. 87:756-765.

Oh, C.-S., and Beer, S. V. 2005. Molecular genetics of Erwinia amylovora involved in the development of fire blight. FEMS (Fed. Eur. Microbiol. Soc.) Microbiol. Lett. 253:185-192.

Oh, C.-S., Kim, J. F., and Beer, S. V. 2005. The Hrp pathogenicity island of Erwinia amylovora and identification of three novel genes required for systemic infection. Mol. Plant Pathol. 6:125-138.

Paulin, J.-P., and Samson, R. 1973. Le feu bactérien en France. II.-caractères des souches d'Erwinia amylovora (Burril) Winslow et al. 1920, isolées du foyer franco-belge. Ann. Phytopathol. 5:389-397.

Petnicki-Ocwieja, T., van Dijk, K., and Alfano, J. R. 2005. The hrpK operon of Pseudomonas syringae pv. tomato DC3000 encodes two proteins secreted by the type III (Hrp) protein secretion system: HopB1 and HrpK, a putative type III translocator. J. Bacteriol. 187:649-663.

Pronk, L. M., and Sanderson, K. E. 2001. Intervening sequences in $r r l$ genes and fragmentation of 23S rRNA in genera of the family Enterobacteriaceae. J. Bacteriol. 183:5782-5787.

Reading, N. C., and Sperandio, V. 2006. Quorum sensing: The many languages of bacteria. FEMS (Fed. Eur. Microbiol. Soc.) Microbiol. Lett. 254:1-11.

Rezzonico, F., and Duffy, B. 2007. The role of $\operatorname{luxS}$ in the fire blight pathogen Erwinia amylovora is limited to metabolism and does not involve quorum sensing. Mol. Plant-Microbe Interact. 20:1284-1297.

Rezzonico, F., and Duffy, B. 2008. Lack of genomic evidence of AI-2 receptors suggests a non-quorum sensing role for $\operatorname{luxS}$ in most bacteria. BMC Microbiol. 8:154.

Roberts, R. G., Hale, C. N., van der Zwet, T., Miller, C. E., and Redlin, S. C. 1998. The potential for spread of Erwinia amylovora and fire blight via commercial apple fruit; a critical review and risk assessment. Crop Prot. 17:19-28.

Salm, H., and Geider, K. 2004. Real-time PCR for detection and quantification of Erwinia amylovora, the causative agent of fireblight. Plant Pathol. 53:602-610.

Salzberg, S. L., Delcher, A. L., Kasif, S., and White, O. 1998. Microbial gene identification using interpolated Markov models. Nucleic Acids Res. 26:544-548.
Schnabel, E. L., and Jones, A. L. 1998. Instability of a pEa29 marker in Erwinia amylovora previously used for strain characterization. Plant Dis. 82:1334-1336.

Smits, T. H. M., Jaenicke, S., Rezzonico, F., Kamber, T., Goesmann, A. Frey, J. E., and Duffy, B. Complete genome sequence of the fire blight pathogen Erwinia pyrifoliae DSM $12163^{\mathrm{T}}$ and comparative genomic insights into plant pathogenicity. BMC Genomics 11:2

Sorek, R., Kunin, V., and Hugenholtz, P. 2008. CRISPR - a widespread system that provides acquired resistance against phages in bacteria and archaea. Nat. Rev. Microbiol. 6:181-186.

Taga, M. E., Miller, S. T., and Bassler, B. L. 2003. Lsr-mediated transport and processing of AI-2 in Salmonella typhimurium. Mol. Microbiol. 50:1411-1427.

Thomson, S. V. 2000. Epidemiology of fire blight. Pages 9-36 in: Fire Blight: The Disease and Its Causative Agent, Erwinia amylovora. J. L. Vanneste, ed. CAB International, Wallingford, U.K.

Toth, I. K., Pritchard, L., and Birch, P. J. R. 2006. Comparative genomics reveals what makes an enterobacterial plant pathogen. Annu. Rev. Phytopathol. 44:305-336

Venturi, V., Venuti, C., Devescovi, G., Lucchese, C., Friscina, A., Degrassi, G., Aguilar, C., and Mazzuchi, U. 2004. The plant pathogen Erwinia amylovora produces acyl-homoserine lactone signal molecules in vitro and in planta. FEMS (Fed. Eur. Microbiol. Soc.) Microbiol. Lett. 241:179-183

Wang, X., de Boer, P. A. J., and Rothfield, L. I. 1991. A factor that positively regulates cell division by activating transcription of the major cluster of essential cell division genes of Escherichia coli. EMBO (Eur. Mol. Biol. Organ.) J. 10:3363-3372.

Winzer, K., Hardie, K. R., and Williams, P. 2003. LuxS and autoinducer-2: Their contribution to quorum sensing and metabolism in bacteria. Adv. Appl. Microbiol. 53:291-396.

Zhang, Y., and Geider, K. 1997. Differentiation of Erwinia amylovora strains by pulsed-field gel electrophoresis. Appl. Environ. Microbiol. 63:4421-4426.

Zhang, Y., Bak, D. D., Heid, H., and Geider, K. 1999. Molecular characterization of a protease secreted by Erwinia amylovora. J. Mol. Biol. 289:1239-1251.

Zhao, Y., Blumer, S. E., and Sundin, G. W. 2005. Identification of Erwinia amylovora genes induced during infection of immature pear tissue. J. Bacteriol. 187:8088-8103.

Zhao, Y., He, S. Y., and Sundin, G. W. 2006. The Erwinia amylovora avrRpt $2_{\mathrm{EA}}$ gene contributes to virulence on pear and AvrRpt $2_{\mathrm{EA}}$ is recognized by Arabidopsis RPS2 when expressed in Pseudomonas syringae. Mol. Plant-Microbe Interact. 19:644-654.

Zhao, Y., Sundin, G. W., and Wang, D. 2009. Construction and analysis of pathogenicity island deletion mutants of Erwinia amylovora. Can. J. Microbiol. 55:457-464.

\section{AUTHOR-RECOMMENDED INTERNET RESOURCES}

\section{CRISPRFinder database:} crispr.u-psud.fr/crispr/CRISPRdatabase.php?page=own

The Sanger Institute E. amylovora BLAST server: www.sanger.ac.uk/cgi-bin/blast/submitblast/e_amylovora

The Sanger Institute Erwinia amylovora webpage: www.sanger.ac.uk/Projects/E_amylovora

Transport Classification database (TCDB): www.tcdb.org 